\title{
A polypyrrole-based solid-contact Pb2+-selective PVC-membrane electrode with a nanomolar detection limit
}

\section{Journal Article}

Author(s):

Sutter, Jolanda; Lindner, Ernö; Gyurcsányi, Robert E.; Pretsch, Ernö

Publication date:

2004

Permanent link:

https://doi.org/10.3929/ethz-b-000160895

Rights / license:

In Copyright - Non-Commercial Use Permitted

Originally published in:

Analytical and Bioanalytical Chemistry 380(1), https://doi.org/10.1007/s00216-004-2737-4 


\section{A polypyrrole-based solid-contact $\mathrm{Pb}^{2+}$-selective PVC-membrane electrode with a nanomolar detection limit}

Received: 28 May 2004/ Revised: 22 June 2004/ Accepted: 22 June 2004 / Published online: 7 August 2004

(C) Springer-Verlag 2004

\begin{abstract}
Ion-selective electrodes (ISE) based on conventional plasticized PVC membranes with solid inner contact (SC) have so far had unsatisfactory lower detection limits. Here it is shown that electropolymerization of pyrrole in the presence of potassium hexacyanoferrate(II)/(III) on $\mathrm{Pt}$ results in adequate inner contact for SC-ISE. The nanomolar lower detection limit achieved with the $\mathrm{Pb}^{2+}$-selective PVC membranes investigated is comparable with values obtained with optimized internal solutions of liquid-contact ISE.
\end{abstract}

Keywords Ion-selective electrode - Solid contact . Polypyrrole $\cdot$ Lower detection limit

\section{Introduction}

Polymeric membrane ion-selective electrodes (ISE) [1-3] have been described for about 60 different ions. In their most frequently used construction, the inner surface of the membrane is in contact with an internal solution which, in turn, surrounds the inner reference electrode. This arrangement guarantees high potential stability but has been shown to be, at least partly, the origin of zerocurrent transmembrane ion fluxes [4, 5]. Conventionally, the internal electrolyte contains a salt of the primary ion, which, however, induces a flux of these ions into the

\footnotetext{
J. Sutter $(\varangle) \cdot$ E. Pretsch

Laboratorium für Organische Chemie,

ETH Hönggerberg, CH-8093 Zürich,

Switzerland

E-mail: pretsch@org.chem.ethz.ch

E. Lindner

Department of Biomedical Engineering,

The University of Memphis, 330 Engineering Technology, Memphis, TN 38152-3210, USA

R. E. Gyurcsányi

Institute of General and Analytical Chemistry,

Budapest University of Technology and Economics,

Szt. Gellért tér 4, 1111 Budapest, Hungary
}

sample, thereby biassing the lower detection limit and the measurement of selectivity coefficients [6]. By reducing [7, 8] or compensating for these fluxes [9, 10], the lower detection limit and selectivity behavior of a series of ISE have been improved by many orders of magnitude [6]. Because the internal solution is, at least in part, the source of such biassing effects, it is expected that ISE with a solid inner contact (SC) should have improved characteristics. They would also enable true miniaturization without biassing selectivity and lower detection limits.

ISE with a solid inner contact, known as coated-wire electrodes, were introduced many years ago [11-13]. It was, however, reported that their long-term potential stability was limited and they were, therefore, useful only in specific applications such as detectors for capillary electrophoresis [14] or in flow-injection analysis [15]. Their potential instability was attributed to lack of control of the concentrations of the species defining the redox potential at the membrane/metal interface $[12,16$, 17] and their response characteristics were successfully improved by adding an appropriate redox-active component to the PVC membrane [18] or by using an intermediate redox-active polymer layer [19]. Similarly, the presence of a redox-active self-assembled monolayer (SAM) between the polymeric membrane and the inner Au electrode also leads to very stable systems [20, 21]. In numerous contributions, the metal surface has been covered by conducting polymers $(\mathrm{CP})$ such as polypyrrole (PPy) [22-25], polyaniline [26], poly(3-octylthiophene) (POT) [27-29], and poly(3,4-ethylenedioxythiophene) $[30,31]$. The potential stability of these so-called allsolid-state ISE was, indeed, massively improved but their lower detection limits were usually even less good than for conventional liquid-contact ISE.

It has recently been demonstrated that fluxes of primary ions also affect the lower detection limit of CP-based SC-ISE [32, 33]. When electropolymerized poly (3-methylthiophene) on glassy carbon was used as the internal layer of a solvent-cast $\mathrm{Ca}^{2+}$-selective PVC membrane, its lower detection limit was not as good as that of an equivalent ISE with a liquid inner contact (LC). On the 
other hand, impregnation of the conducting polymer with a solution of EDTA and $\mathrm{CaCl}_{2}$ at $\mathrm{pH} 10$ resulted in an apparently super-Nernstian response [32] as is known for liquid-contact ISE with ion-buffered internal solutions [8]. The detection limit of CP-based SC-ISE has been improved by applying an external current [32, 34], similarly to earlier experiments with LC-ISE [9, 10, 35].

For PPy or other conducting polymers with functional groups that can be protonated, one possible reason for the above-mentioned primary ion fluxes into the sample is the spontaneous self-discharge of these polymers $[32,36]$. Accumulation of primary ions in water residues present in the $\mathrm{CP}$ layer or in a thin water film formed between the $\mathrm{CP}$ and the membrane during the conditioning of the ISE is another feasible source of ion fluxes. To test for the presence of a water film the ISE are first conditioned in a solution of the primary ion. The sample is then replaced with a solution of an interfering ion. When an inner water film is present the initial negative potential step is followed by positive drift, because primary ions in the water film are slowly substituted by interfering ions [37]. On replacing the solution with the original solution of the primary ion the initial positive potential step is followed by a negative drift because, now, interfering ions of the inner film are exchanged for primary ions. Because the ISE membrane prefers the latter, the second potential drift is slower than the first [37]. On the basis of such experiments, the presence of a water film has been proved with Au electrodes in the absence of a lipophilic SAM [37] and with electropolymerized POT as the inner CP layer of SC-ISE [38]. In contrast, no indication of a water layer was found with solvent-cast POT as inner CP layer and poly(methyl methacrylate)/poly(decyl methacrylate) (MMA/DMA) copolymer as membrane matrix [38]. The lower detection limit was much worse when the water-layer test was positive, which strongly indicates that this water layer is the cause of primary ion fluxes. It was recently shown that water-layer tests are also negative with PPy that had been electropolymerized in the presence of potassium hexacyanoferrate(II)/(III) [39]. This was the first time that no water layer had been observed with PVC membranes of conventional composition, because previously the absence of a water film had only been observed with SAM- or CP-based SC-ISE, either with other polymers $[20,21,38]$ or with membranes containing less than the usual amount of plasticizer [20, 21]. In this paper, we show for the first time that it is possible to achieve nanomolar detection limits with conventional plasticized PVC membranes using CP-based SC-ISE.

\section{Experimental}

\section{Reagents}

Poly(3-octylthiophene) (POT) was obtained from Applications Chemistry and Technologies (Saint-Egrève,
France). Pyrrole Purum (Fluka, Buchs, Switzerland) was distilled before use and kept under Ar at low temperature in the dark. The lead ionophore, tert-butylcalix[4]arenetetrakis $(N, N$-dimethylthioacetamide), sodium tetrakis [3,5-bis(trifluoromethyl)phenyl]borate (NaTFPB), tetradodecylammonium tetrakis-(4-chlorophenyl)borate (ETH 500), bis(2-ethylhexyl) sebacate (DOS), poly(vinyl chloride) (PVC), and cyclohexanone (all Selectophore grade), potassium hexacyanoferrate(II) trihydrate $\left(\mathrm{K}_{4} \mathrm{Fe}(\mathrm{CN})_{6} \cdot 3 \mathrm{H}_{2} \mathrm{O}\right), \mathrm{CH}_{2} \mathrm{Cl}_{2}, \mathrm{CHCl}_{3}$ (all Puriss. p.a.), and $\mathrm{Pb}\left(\mathrm{NO}_{3}\right)_{2}$ (lead ion chromatography standard solution, $1.0 \mathrm{~g} \mathrm{~L}^{-1}$, in $\mathrm{HNO}_{3}$ ) were from Fluka. Titrisol $\mathrm{HCl}$ $\left(1 \mathrm{~mol} \mathrm{~L}^{-1}\right)$ and $\mathrm{CaCl}_{2}, \mathrm{NaCl}, \mathrm{KCl}$, and $\mathrm{HNO}_{3}(65 \%)$ Suprapur were from Merck (Darmstadt, Germany). Aqueous solutions were prepared with deionized water (specific resistance: $18 \mathrm{M} \Omega \mathrm{cm}$; Nanopure; Barnstead, Basel, Switzerland).

\section{Preparation of solid inner contacts}

Two different types of electrode were prepared for polypyrrole (PPy) solid-contact ISE. On the one hand, screen-printed Pt electrodes described elsewhere [39] were used in a specially designed flow-through cell (Fig. 1). Before further treatment the electrodes were cleaned in $\mathrm{O}_{2}$ plasma (pressure, $1.7 \times 10^{-2}$ mbar; MCS 020 instrument, Balzers, Liechtenstein). On the other hand, Au tips of rotating-disk electrodes (Au disk $\varnothing$, $3 \mathrm{~mm}$; body $\varnothing, 10 \mathrm{~mm}$; type 6.1204.020, Metrohm, Herisau, Switzerland) were polished with alumina (Metrohm) and rinsed with water and $\mathrm{CH}_{2} \mathrm{Cl}_{2}$ before depositing PPy.

Electrochemical polymerization of pyrrole was performed in a one-compartment three-electrode electrochemical cell with a $\mu$ Autolab Type II potentiostat/ galvanostat (Eco Chemie, Utrecht, Netherlands). A Ag/ $\mathrm{AgCl} / 3 \mathrm{~mol} \mathrm{~L}^{-1} \mathrm{KCl}$ electrode (Bioanalytical Systems, West Lafayette, USA) was used as reference and a Pt wire as counter electrode. Potassium hexacyanoferrate(II)/(III)-doped PPy films were deposited on the above-mentioned $\mathrm{Pt}$ electrodes and $\mathrm{Au}$ disk electrodes by potentiostatic electropolymerization in an aqueous solution of $0.5 \mathrm{~mol} \mathrm{~L}^{-1}$ pyrrole and $0.5 \mathrm{~mol} \mathrm{~L}^{-1}$ $\mathrm{K}_{4} \mathrm{Fe}(\mathrm{CN})_{6}$, (cf. Ref. [39]), which was purged with $\mathrm{Ar}$ before electropolymerization. A potential of $1 \mathrm{~V}$ was applied for $90 \mathrm{~s}$ for Pt electrodes and only $40 \mathrm{~s}$ for $\mathrm{Au}$ disk electrodes, because after $90 \mathrm{~s}$ the thick PPy layer came off easily. Generally, the deposition of the PPy film was performed simultaneously on 3-5 electrically connected individual electrodes of five-site Pt electrode arrays. After electropolymerization the electrodes were rinsed with water. On the basis of preliminary experiments (see Results and discussion), they were generally left soaking in water for $4 \mathrm{~h}$ and rinsed again with water. The PPy films were then dried at room temperature and rinsed with small amounts of tetrahydrofuran to remove residual traces of water. The presence of hexacyanoferrate (II)/(III) in the polypyr- 
Fig. 1 Construction of solidcontact ISE. Au disk electrode with PPy as $\mathrm{SC}$ and $\mathrm{Pb}^{2+}$-ISE membrane (DOS-PVC) (Top). Screen-printed Pt electrodes in flow-through cell (Center, bottom)

\section{Au disk electrode}
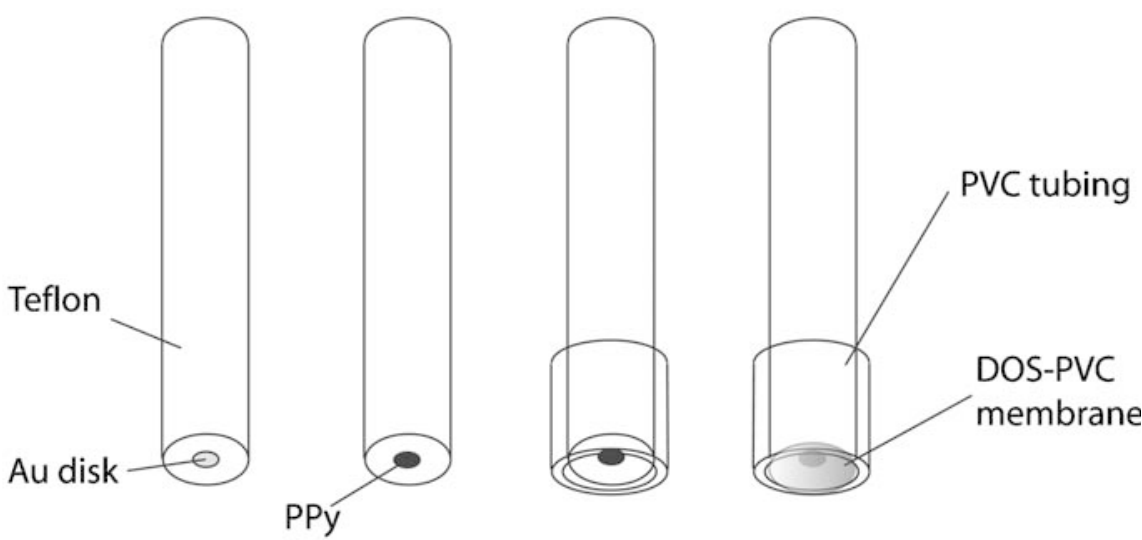

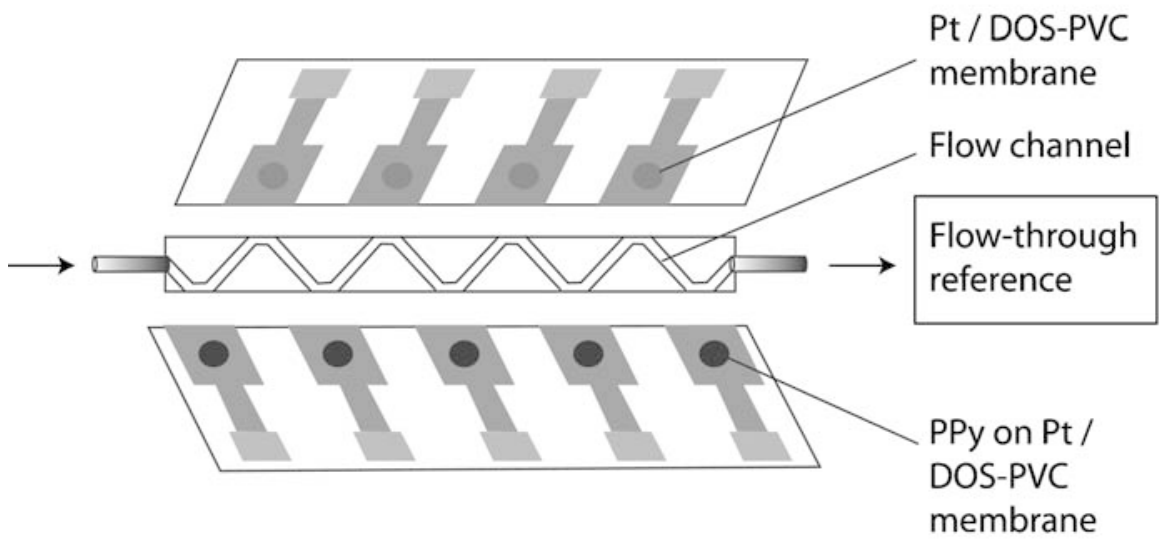

Flow-through cell, top view

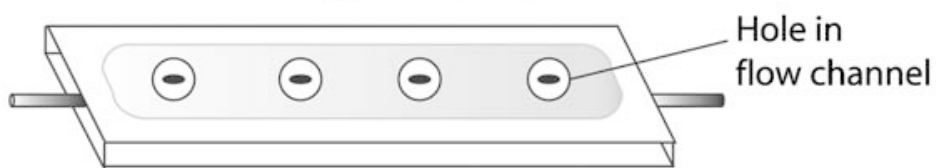

role film was confirmed by cyclic voltammetry (results not shown).

Gold-coated silicon wafers with a POT solid contact were used in the same flow-through cell as described for PPy/Pt SC-ISE. Before POT was applied the silicon wafers were rinsed with water and acetone and dried in Ar. Gold layers, $200 \mathrm{~nm}$ thick, were obtained by thermal evaporation of $\mathrm{Au}(99.99 \%$, Johnson Matthey, Zürich, Switzerland) with a deposition rate of $2 \mathrm{~nm} \mathrm{~s}^{-1}$ on to wafers covered with a $6 \mathrm{~nm}$ layer of $\mathrm{Cr}(99.99 \%$, Balzers) using a MED 010 instrument (Balzers) at a pressure of ca. $10^{-3} \mathrm{~Pa}$. The polymer POT was applied to the Au-coated silicon wafers by drop-casting $2 \times 10 \mu \mathrm{L}$ of a $0.25 \mathrm{mmol} \mathrm{\textrm {L } ^ { - 1 }}$ solution (calculated for the monomer) in $\mathrm{CHCl}_{3}$ resulting in a layer of ca. $5 \mathrm{~mm}$ diameter, which was dry after $2 \mathrm{~min}$.
ISE membranes and electrodes

The $\mathrm{Pb}^{2+}$-selective membranes for SC-ISE contained $\mathrm{Pb}^{2+}$ ionophore $\left(0.07 \mathrm{wt} \%, 0.7 \mathrm{mmol} \mathrm{kg}{ }^{-1}\right)$, NaTFPB $\left(0.03 \mathrm{wt} \%, \quad 0.3 \mathrm{mmol} \mathrm{kg}^{-1}\right)$, ETH $500 \quad(1.3 \mathrm{wt} \%$, $\left.11.5 \mathrm{mmol} \mathrm{kg}^{-1}\right)$, DOS $(62.1 \mathrm{wt} \%)$, and PVC (36.5 wt \%) for PbM1 (membrane with low concentration of ionophore and NaTFPB, cf. [40]), and $\mathrm{Pb}^{2+}$ ionophore $\left(1.0 \mathrm{wt} \%, 9.6 \mathrm{mmol} \mathrm{\textrm {kg } ^ { - 1 }}\right)$, NaTFPB $(0.44$ $\left.\mathrm{wt} \%, 5.0 \mathrm{mmol} \mathrm{kg}{ }^{-1}\right)$, ETH $500(1.1 \mathrm{wt} \%, 9.6 \mathrm{mmol}$ $\left.\mathrm{kg}^{-1}\right)$, DOS (61.8 $\left.\mathrm{wt} \%\right)$, and PVC (35.6 $\mathrm{wt} \%$ ) for PbM2 (membrane of conventional composition). The membranes were prepared by dissolving the components in cyclohexanone $(418.4 \mathrm{mg}$ in $2.8 \mathrm{~mL}$ for $\mathrm{PbM} 1$ and $208.6 \mathrm{mg}$ in $1.4 \mathrm{~mL}$ for $\mathrm{PbM} 2$ ). The corresponding solutions for $\mathrm{Pb}^{2+}$-selective membranes for POT SCISE and LC-ISE used for selectivity measurements were 
poured into glass rings (i.d., $7 \mathrm{~cm}$ for PbM1 and $5 \mathrm{~cm}$ for $\mathrm{PbM} 2$ ). Overnight evaporation yielded transparent membranes. For LC-ISE, a disk of $5 \mathrm{~mm} \varnothing$ was punched from the membrane and glued to PVC tubing with a PVC-THF slurry. The internal filling solution was $10^{-2} \mathrm{~mol} \mathrm{~L}^{-1} \mathrm{NaCl}$.

When the PPy coatings on the Pt electrodes were dry, $7 \mu \mathrm{L}$ of the respective membrane solution was drop-cast on to the sensing area, also spreading around it (cf. [39]). When dry, an additional $7 \mu \mathrm{L}$ of membrane solution was applied. For ISE of the coated-wire type the membrane solution was directly drop-cast on to the Pt electrodes. When dry, a five-site array of Pt/PPy electrodes and a four-site array of coated-wire type ISE were assembled in the flow-through cell in such a way that the membranes were pressed from both sides on to the holes in the zigzag flow channel of the plexiglass cell. Mechanical fixation was provided by silicon rubber springs pressing against the cell walls.

For Au disk electrodes a piece of PVC tubing (ca. $2 \mathrm{~cm}$ ) was placed on the electrode tip (Fig. 1). This tight PVC contact enabled casting of ca. $60 \mu \mathrm{L}$ membrane solution on the top of the PPy-covered electrode (Fig. 1). It was left to dry overnight at room temperature. The Au disk electrodes without PPy were prepared analogously.

For POT SC-ISE, a disk of $4 \mathrm{~mm} \varnothing$ was punched from the $\mathrm{Pb}^{2+}$-ISE membrane and placed on the POT layer. Coated-wire-type electrodes were prepared by placing the membrane directly on the Au surface. Then, five POT SC-ISE and four coated-wire type ISE were assembled in five-site and four-site arrays, respectively. These two arrays were then assembled in the flowthrough cell in the same way as for the PPy/Pt SC-ISE.

\section{EMF measurements}

Potentials were measured with a custom-made 14-channel electrode monitor at room temperature $\left(22^{\circ} \mathrm{C}\right)$. The flow-through cell was connected to a peristaltic pump (type ISM597A V.10, Ismatec, Zürich, Switzerland) letting the solution pass at a flow rate of $0.21 \mathrm{~mL} \mathrm{~min}^{-1}$. A flow-through $\mathrm{Hg} / \mathrm{Hg}_{2} \mathrm{Cl}_{2} /$ sat. $\mathrm{KCl}$ reference electrode with $3 \mathrm{~mol} \mathrm{~L}^{-1} \mathrm{KCl}$ as bridge electrolyte (type OP-0829P-S, Radelkis, Budapest, Hungary) was placed downstream from the cell. The bridge electrolyte was continuously pumped through the salt bridge compartment of the reference block and its stream joined the sample effluent from the flow-through cell. For measurements with $\mathrm{Au}$ disk electrodes and LC-ISE, a double-junction $\mathrm{Ag} / \mathrm{AgCl} / 3 \mathrm{~mol} \mathrm{~L}^{-1} \mathrm{KCl}$ reference electrode (type 6.0729.100, Metrohm) containing $1 \mathrm{~mol} \mathrm{~L}^{-1} \mathrm{NH}_{4} \mathrm{NO}_{3}$ as bridge electrolyte was used. Experiments were performed in a $500 \mathrm{~mL}$ poly(ethylene) beaker pretreated overnight in $10^{-4} \mathrm{~mol} \mathrm{~L}^{-1} \mathrm{HNO}_{3}$ in stirred solutions.

All EMF values were corrected for liquid-junction potentials according to the Henderson equation.
Activity coefficients were calculated by use of the Debye-Hückel approximation. For measurements in dilute solutions the SC-ISE were conditioned, first, for at least 2 days in $10^{-5} \mathrm{~mol} \mathrm{~L}^{-1} \mathrm{~Pb}\left(\mathrm{NO}_{3}\right)_{2}$ and then overnight in $10^{-6} \mathrm{~mol} \mathrm{~L}^{-1}$ (for measurements from high to low concentrations) or in $10^{-10} \mathrm{~mol} \mathrm{~L}^{-1} \mathrm{~Pb}\left(\mathrm{NO}_{3}\right)_{2}$ for measurements from low to high concentrations, both with $10^{-4} \mathrm{~mol} \mathrm{~L}^{-1} \mathrm{HNO}_{3}$ and $10^{-3} \mathrm{~mol} \mathrm{~L}^{-1}$ $\mathrm{CaCl}_{2}$ as ion background. This same background was used with all $\mathrm{Pb}\left(\mathrm{NO}_{3}\right)_{2}$ sample solutions. For selectivity measurements according to the separate solution method [41, 42], LC-ISE were conditioned in $10^{-2} \mathrm{~mol} \mathrm{~L}^{-1} \mathrm{NaCl}$.

\section{Results and discussion}

To obtain a SC-ISE of high potential stability and good lower detection limit, the following requirements must be met:

controlled redox potential between membrane and solid contact [12, 17, 19];

absence of a water film between membrane and metal electrode [37]; and

no spontaneous redox processes within the $\mathrm{CP}$ layer $[32,36]$.

Violation of requirements 1 and 2 is indicated by potential drifts on alternate bubbling of $\mathrm{Ar}$ or $\mathrm{O}_{2}$ through the sample and when a solution containing only primary ions is replaced by another solution containing interfering ions or vice versa [37], respectively. Very recently, subnanomolar detection limits were obtained with a $\mathrm{Pb}^{2+}$-selective MMA/DMA membrane using drop-cast POT as inner CP layer [38]. So far however, the detection limits achieved with SCISE based on conventional PVC membranes containing ca. $66 \mathrm{wt} \%$ of plasticizer have, in no way, been so low. In this work, such conventional membranes are investigated with drop-cast POT or with a PPy solid inner contact. In combination with a $\mathrm{K}^{+}$-selective DOS-PVC membrane the PPy films electropolymerized in the presence of potassium hexacyanoferrate(II)/(III) showed no indications of the presence of a water film [39]. For batch measurements $\mathrm{Au}$ disk electrodes with PPy have been used; for measurements in the flowthrough cell, screen-printed Pt electrodes with PPy or freshly prepared $\mathrm{Au}$ slides with POT have been implemented.

Preliminary tests were performed in the flow-through cell (Fig. 1) with drop-cast POT on Au and DOS-PVC membranes. Unfortunately, the lower detection limit of this system, $10^{-7.5} \mathrm{~mol} \mathrm{~L}^{-1} \mathrm{~Pb}^{2+}$ (results not given), was insufficient. When disassembling the cell, the orange colour of the PVC membrane indicated that POT had been diffusing into the membrane and, obviously, caused its selectivity to deteriorate. No such effects were observed with the MMA/DMA membranes [38], presumably because of the much lower diffusion coefficients 


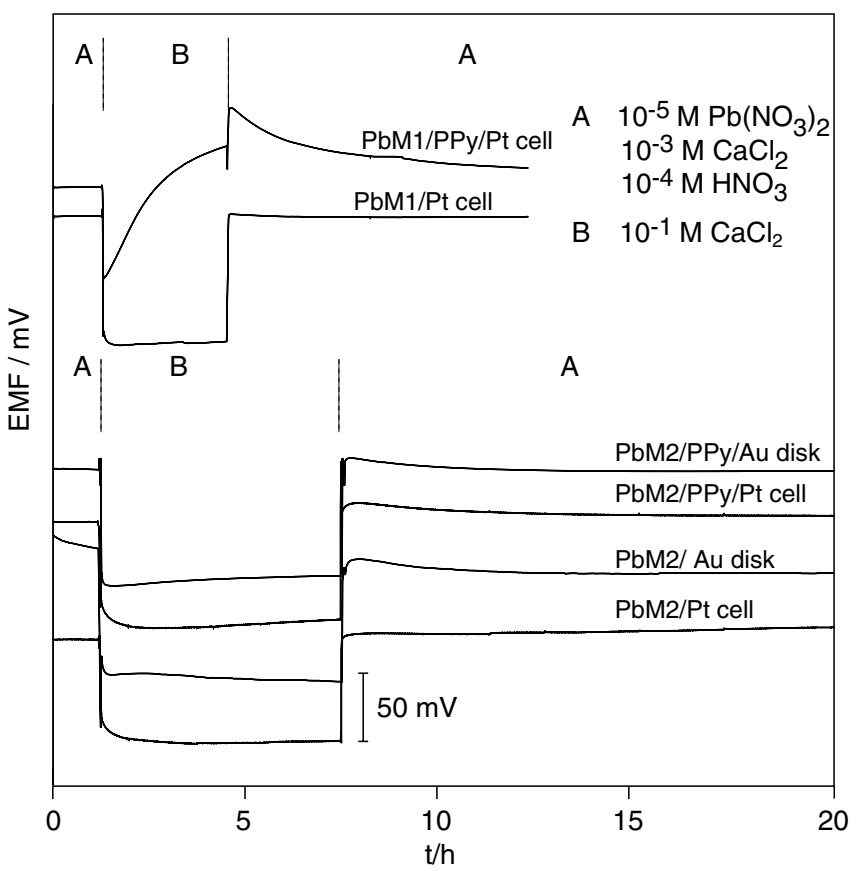

Fig. 2 Water-layer tests on solid-contact DOS-PVC membrane electrodes with and without conducting polymer layer. A significant water layer was observed only with PPy-based solid-contact ISE which had been briefly rinsed with water after electropolymerization. All other conducting polymer layers were soaked in water for $4 \mathrm{~h}$

in such copolymers [43]. Further experiments were performed with PPy electropolymerized in the presence of potassium hexacyanoferrate(II)/(III) [39]. Surprisingly, at first, the presence of a water layer was indicated by strong potential drifts observed when replacing the $\mathrm{Pb}\left(\mathrm{NO}_{3}\right)_{2}$ sample solution with $\mathrm{CaCl}_{2}$ and vice versa (Fig. 2, top trace), whereas no such drifts occurred in the absence of the CP layer (trace 2 from top). However, such systems lack robust redox control on the metal surface and are, therefore, susceptible to changes in the $\mathrm{O}_{2}$ content of the sample (see below). The formation of a water layer with PPy can be avoided by thorough washing (over $4 \mathrm{~h}$ ) to remove excess potassium hexacyanoferrate(II)/(III). Indeed, only slight drifts were observed after such a procedure both with the screenprinted Pt electrodes in the flow-through cell and with the $\mathrm{Au}$ disk electrodes during batch measurements (Fig. 2, traces 3 and 4 from top). Also, the ISE without the conducting polymer behaved similarly (Fig. 2, two bottom traces). The results indicate that the preparation of CP layers is crucial and they can be the very reason for the accumulation of a significant amount of water (see also [38]).

The importance of a CP layer is demonstrated by Fig. 3. Fluctuations in the $\mathrm{O}_{2}$ concentration resulted in large changes of $>20 \mathrm{mV}$ in the EMF of the ISE without a conducting polymer. The $\mathrm{O}_{2}$ concentration changes were introduced by bubbling $\mathrm{O}_{2}$ or Ar through the sample. Similar changes of opposite sign occur on

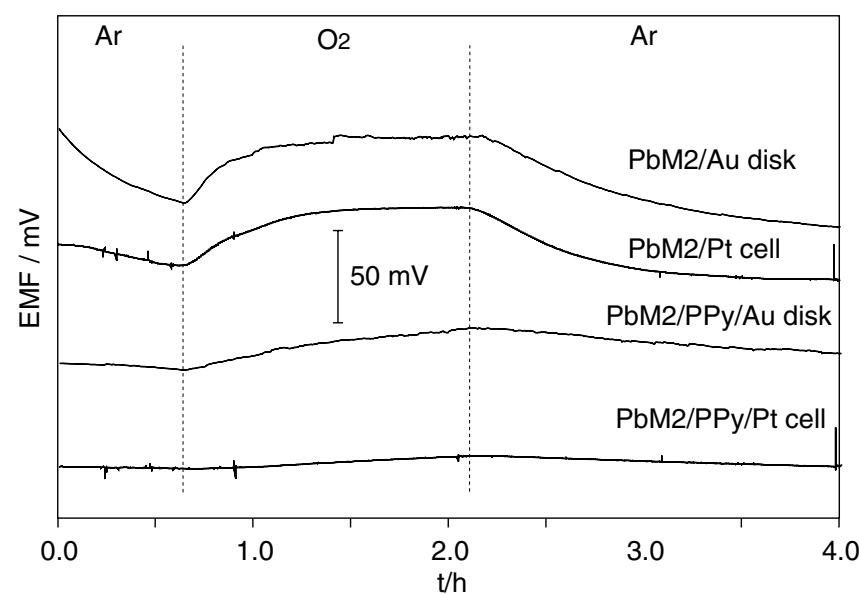

Fig. 3 Influence of $\mathrm{O}_{2}$ on the EMF of $\mathrm{Pb}^{2+}$-selective solid-contact DOS-PVC electrodes with and without conducting polymer layer

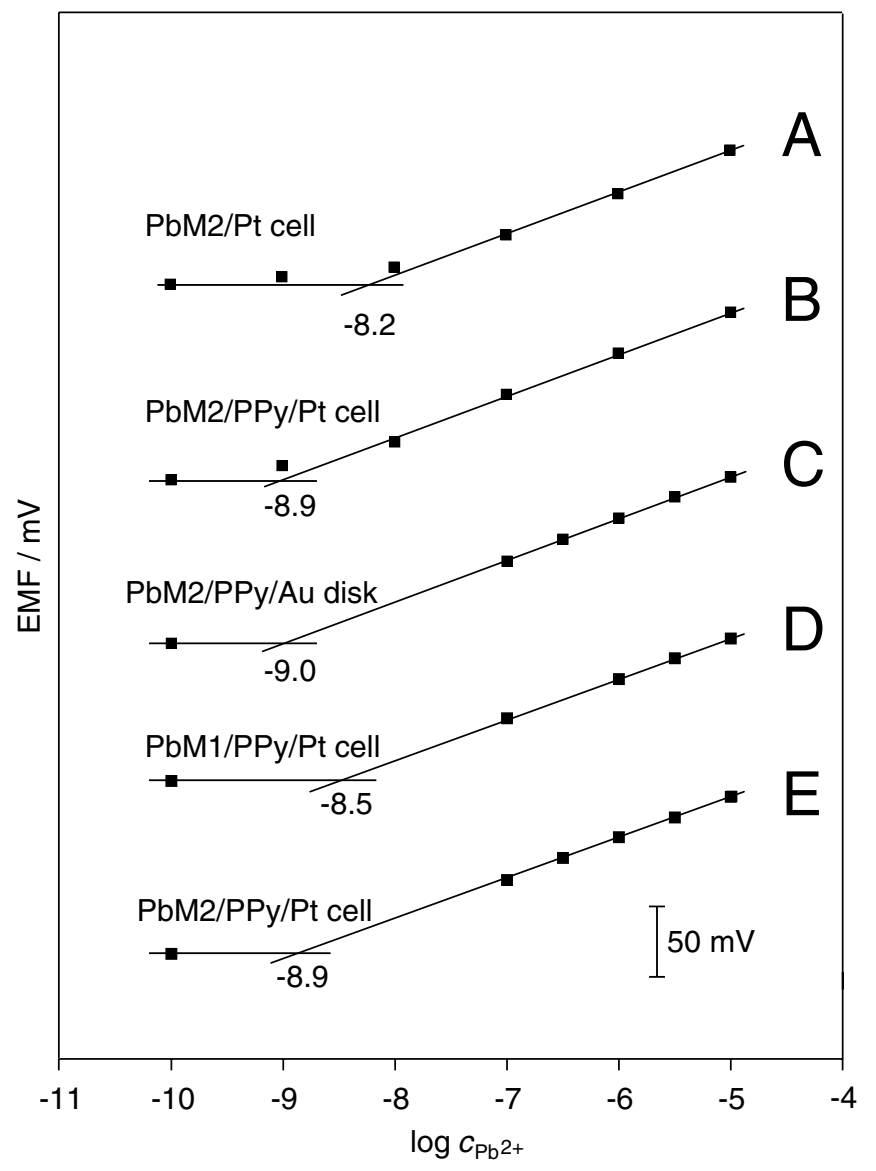

Fig. 4 Calibration curves obtained by successively decreasing ( $A$, $B)$ or increasing $(D, E)$ the sample concentration in the flow through cell with $\mathrm{PPy} /$ screen-printed $\mathrm{Pt}(B, D, E)$ and screenprinted $\mathrm{Pt}(A)$ covered with membranes $\mathrm{PbM} 1(D)$ or $\mathrm{PbM} 2(A, B$, $E)$. Curve $C$ was obtained with $\mathrm{PPy} / \mathrm{Au}$ disk electrodes covered with $\mathrm{PbM} 2$ by successively increasing the sample concentration in batch mode

removing $\mathrm{O}_{2}$ with Ar. The effect is much smaller for analogous $\mathrm{Pb}^{2+}$-ISE with PPy but it is still significant for the Au disk electrode. For the screen-printed Pt in 
Table 1 Potentiometric selectivity coefficients, $\log K_{\mathrm{Pb} J}^{\mathrm{pot}}$, and response slopes (in parentheses, $\mathrm{mV}$ decade $^{-1}$, concentration range, $10^{-1}-10^{-4} \mathrm{~mol} \mathrm{~L}^{-1}$ ) obtained with liquid-contact ISE for membranes PbM1 and PbM2 (SD, $n=5)$

\begin{tabular}{lll}
\hline Ion & PbM1 & PbM2 \\
\hline $\mathrm{Na}^{+}$ & $-6.3 \pm 0.2(58.2 \pm 3.5)$ & $-6.3 \pm 0.1(58.1 \pm 0.1)$ \\
$\mathrm{K}^{+}$ & $-6.3 \pm 0.1(56.8 \pm 1.1)$ & $-6.6 \pm 0.1(56.9 \pm 0.2)$ \\
$\mathrm{H}^{+}$ & $-3.5 \pm 0.3(43.7 \pm 2.0)$ & $-7.3 \pm 0.3(46.3 \pm 03)$ \\
$\mathrm{Ca}^{2+}$ & $-12.3 \pm 0.1(23.7 \pm 0.8)$ & $-13.6 \pm 0.2(23.7 \pm 0.2)$ \\
\hline
\end{tabular}

the flow-through cell it is $<2 \mathrm{mV}$. Note that thicker polymeric films could be prepared on the rougher screen-printed platinum than on the smooth gold electrodes (Experimental section); this affects the oxygen sensitivity of the respective ISE.

The lower detection limits are $10^{-9}$ and $10^{-8.9} \mathrm{~mol} \mathrm{~L}^{-1} \mathrm{~Pb}^{2+}$ with the $\mathrm{Au}$ disk electrode in the batch mode and the screen-printed Pt electrode in the flow-through cell, respectively (Fig. 4). There is no significant difference between the responses when performing the calibration from high to low (Fig. 4B) or from low to high (Fig. 4E) concentrations. The beneficial effect of the polymeric solid contact is also demonstrated by the almost one order of magnitude lower detection limit of these electrodes compared with the simple, coated wire type ISE (Figs. 4A, B). Because of less good discrimination of $\mathrm{H}^{+}$with the membrane PbM1 (Table 1), which had a smaller concentration of $\mathrm{Pb}^{2+}$-ionophore and ionic sites [40], its lower detection limit of $10^{-8.5} \mathrm{~mol} \mathrm{~L}^{-1} \mathrm{~Pb}^{2+}$ was slightly worse. The electrodes with a CP inner contact had better long-term stability and superior lower detection limits, especially with a PPy deposition time of $90 \mathrm{~s}$ on screen-printed $\mathrm{Pt}$ electrodes (Fig. 5). With these, the SC-ISE still had a $10^{-9} \mathrm{~mol} \mathrm{~L}^{-1} \mathrm{~Pb}^{2+}$ detection limit 10 days after the first measurements. This stability is remarkable, because with liquid-contact ISE, nanomolar detection limits usually worsen significantly within a week [40]. Without the CP layer, the initial detection limit of the Pt electrode is less good by about one order of magnitude. Moreover, they show continuous average potential drifts of $>100 \mathrm{mV}$
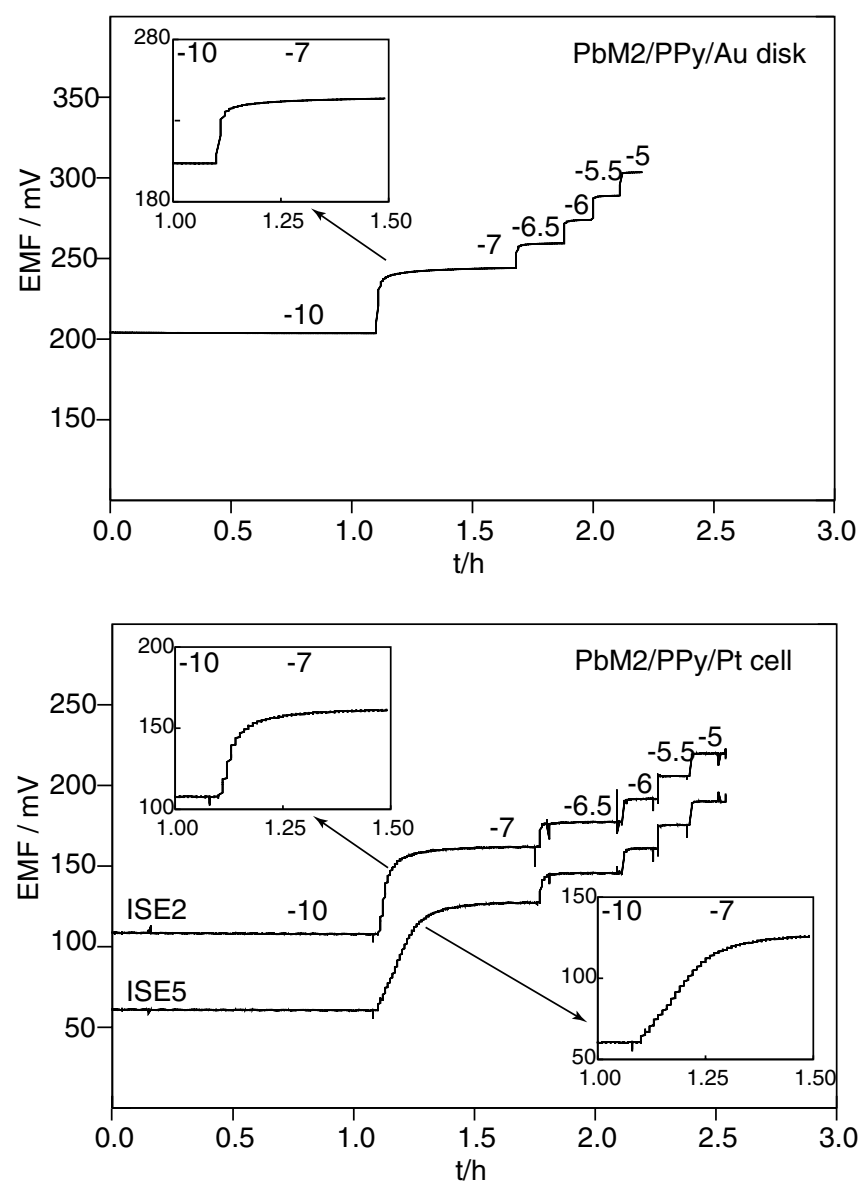

Fig. 6 Time traces of EMF response of PPy-based solid-contact $\mathrm{Pb}^{2+}$-ISE. Au disk in batch mode (top), screen-printed Pt in flowthrough mode (bottom); traces for the second- (ISE2) and lastplaced (ISE5) electrodes in the flow-through cell (cf. Fig. 1)

within 10 days whereas with PPy, the drift is $<1 \mathrm{mV}$ day $^{-1}$.

With liquid-contact ISE, the response times for submicromolar sample concentrations are rather long [40]. With the POT-based MMA/DMA membranes they were much faster. After a concentration step from $10^{-9}$ to $10^{-7.7} \mathrm{~mol} \mathrm{~L}^{-1} \mathrm{~Pb}\left(\mathrm{NO}_{3}\right)_{2}$, the drift was $<0.4 \mathrm{mV}$
Fig. 5 Long-term response behavior of the Au- (left) and Pt-based (right) solid-contact ISE with and without PPy layer. Between measurements the electrodes were kept in the conditioning solution

$\left(10^{-10} \mathrm{~mol} \mathrm{~L}^{-1} \mathrm{~Pb}\left(\mathrm{NO}_{3}\right)_{2}\right.$, with

$10^{-4} \mathrm{~mol} \mathrm{~L}^{-1} \mathrm{HNO}_{3}$ and

$10^{-3} \mathrm{~mol} \mathrm{~L}^{-1} \mathrm{CaCl}_{2}$ as ion background)
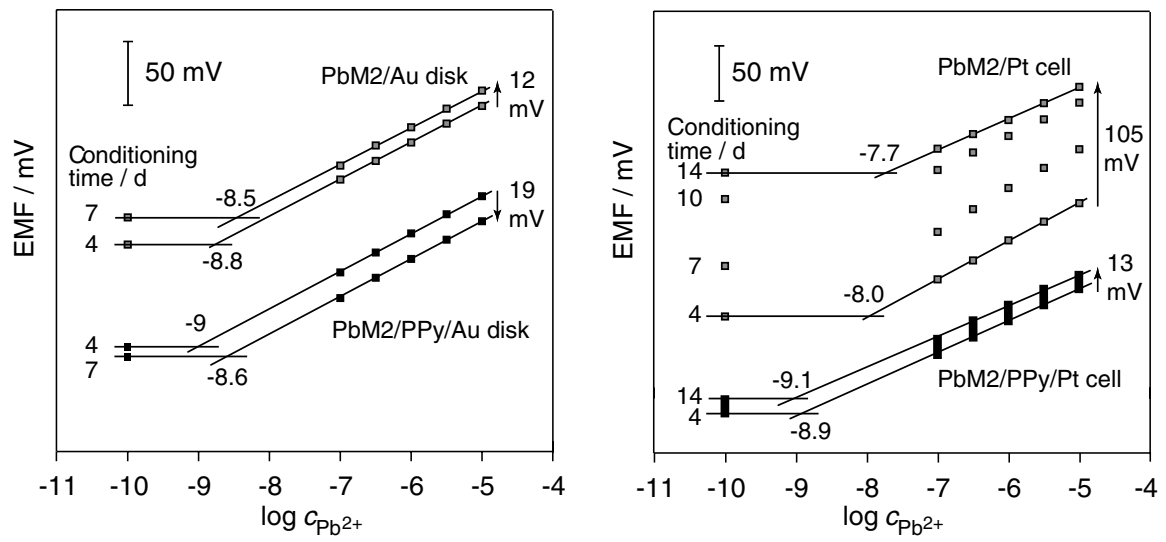
$\min ^{-1}$ after a measuring time of 2 min [38]. With the present $\mathrm{Au}$ disk CP-ISE it was somewhat longer (on changing the concentration from $10^{-10}$ to $10^{-7} \mathrm{~mol} \mathrm{~L}^{-1}$, a drift of $<0.4 \mathrm{mV} \mathrm{m^{-1 }}$ was obtained after $6 \mathrm{~min}$; Fig. 6). In the flow-through cell the same stability was only achieved after 11 and $18 \mathrm{~min}$, respectively, for the second-placed and last-placed electrodes in the cell (Fig. 6) whereas when the concentration was changed from $10^{-7}$ to $10^{-9} \mathrm{~mol} \mathrm{~L}^{-1}$ the required time was $\sim 30 \mathrm{~min}$. This difference indicates that the response time is significantly influenced by the flow-through cell. Trace-level measurements in bulk solutions are usually done with large volumes (typically $100-500 \mathrm{~mL}$ ) and with sample containers preconditioned with the same dilute solutions for a long time. Because this is not possible in a miniaturized flow-through cell, a significant carry-over effect cannot be excluded. This interpretation is supported by the fact that the same response time of 2 min was observed with both systems after changing the sample from $10^{-7}$ to $10^{-6.5} \mathrm{~mol} \mathrm{~L}^{-1} \mathrm{~Pb}\left(\mathrm{NO}_{3}\right)_{2}$, i.e. at concentrations where impurities are less relevant (Fig. 6).

Based on the selectivity coefficients (Table 1), the detection limit in the absence of ion fluxes (static detection limit [44]) defined by the interference of the background electrolytes $\left(10^{-4} \mathrm{~mol} \mathrm{~L}^{-1} \mathrm{HNO}_{3}\right.$, $10^{-3} \mathrm{~mol} \mathrm{~L}^{-1} \mathrm{CaCl}_{2}$ ) should be of the order of $10^{-15} \mathrm{~mol} \mathrm{~L}^{-1}$. The observed detection limit of $10^{-9} \mathrm{~mol} \mathrm{~L}^{-1}$ indicates that, despite the solid contact, the concentration at the membrane surface must be influenced by ions leaching from the membrane into the sample. This is readily understood when recalling that a single membrane contains about $5 \times 10^{-9} \mathrm{~mol} \mathrm{~Pb}^{2+}$. If only $1 \%$ of the ions leave the membrane due to ion exchange or chemical decomposition, this would correspond to the $\mathrm{Pb}^{2+}$ content of a $10-\mathrm{mL}$ sample of $5 \times 10^{-9} \mathrm{~mol} \mathrm{~L}^{-1}$. Because of the expected build-up of a concentration gradient, the concentration at the membrane surface would be $>5 \times 10^{-9} \mathrm{~mol} \mathrm{~L}^{-1} \mathrm{~Pb}^{2+}$. This process is in complete analogy with the primary ion release of a $\mathrm{K}^{+}$-selective LC-ISE with $\mathrm{NaCl}$ as internal solution, where the released $\mathrm{K}^{+}$also originated solely from the membrane [45]. According to these considerations, improvements in the lower detection limits are to be expected by reducing the dimensions of the solidcontact ISE.

\section{Conclusions}

This paper shows for the first time that the lower detection limits achievable with conventional PVC membranes with solid-contact electrodes are about as good as with optimized liquid-contact electrodes. Neither the lower detection limit nor the long-term stability is influenced by spontaneous decomposition of the CP layer. On the basis of these results it will be possible to prepare other solid-contact ISE with lower detection limits, as obtained earlier with optimized internal solutions.

Acknowledgements This work has received financial support from the Swiss National Science Foundation, the National Institutes of Health (grant 8R01EB002189-04), the National Science Foundation (grant 0202207 and 0335228), The Hungarian Academy of Sciences (MTA), and OTKA-NSF 46146 grants. R.E.Gy. gratefully acknowledges the Bólyai János and Varga József (Balla György) fellowships and financial support provided by the Hungarian Scientific Foundation (F037977, F034431, and M041969). We also thank Dr D. Wegmann for careful reading of the manuscript.

\section{References}

1. Buck RP, Lindner E (2001) Anal Chem 73:88A-97A

2. Bakker E, Bühlmann P, Pretsch E (1997) Chem Rev 97:30833132

3. Bühlmann P, Pretsch E, Bakker E (1998) Chem Rev 98:15931687

4. Mathison S, Bakker E (1998) Anal Chem 70:303-309

5. Sokalski T, Ceresa A, Zwickl T, Pretsch E (1997) J Am Chem Soc 119:11347-11348

6. Bakker E, Pretsch E (2002) Anal Chem 74:420A-426A

7. Sokalski T, Zwickl T, Bakker E, Pretsch E (1999) Anal Chem 71:1204-1209

8. Sokalski T, Ceresa A, Fibbioli M, Zwickl T, Bakker E, Pretsch E (1999) Anal Chem 71:1210-1214

9. Lindner E, Gyurcsányi RE, Buck RP (1999) Electroanalysis 11:695-702

10. Pergel E, Gyurcsányi RE, Tóth K, Lindner E (2001) Anal Chem 73:4249-4253

11. Cattrall RW, Freiser H (1971) Anal Chem 43:1905-1906

12. Cattrall RW, Drew DW, Hamilton IC (1975) Anal Chim Acta 76:269-277

13. Cattrall RW, Hamilton IC (1984) Ion-Sel. Electrode Rev 6:125-172

14. Schnierle P, Kappes T, Hauser PC (1998) Anal Chem 70:35853589

15. Dimitrakopoulos T, Farrell JR, Iles PJ (1996) Electroanalysis 8:391-395

16. Buck RP (1976) Anal Chem 48:R23-R39

17. Hulanicki A, Trojanowicz M (1976) Anal Chim Acta 87:411-417

18. Liu D, Meruva RK, Brown RB, Meyerhoff ME (1996) Anal Chim Acta 321:173-183

19. Hauser PC, Chiang DWL, Wright GA (1995) Anal Chim Acta 302:241-248

20. Fibbioli M, Bandyopadhyay K, Liu S-G, Echegoyen L, Enger O, Diederich F, Bühlmann P, Pretsch E (2000) Chem Commun 339-340

21. Fibbioli M, Bandyopadhyay K, Liu S-G, Echegoyen L, Enger O, Diederich F, Gingery D, Bühlmann P, Persson H, Suter UW, Pretsch E (2002) Chem Mater 14:1721-1729

22. Cadogan A, Gao Z, Lewenstam A, Ivaska A, Diamond D (1992) Anal Chem 64:2496-2501

23. Michalska A, Hulanicki A, Lewenstam A (1994) Analyst 119:2417-2420

24. Momma T, Yamamoto M, Komaba S, Osaka T (1996) J Electroanal Chem 407:91-96

25. Michalska A, Hulanicki A, Lewenstam A (1997) Microchem J 57:59-64

26. Bobacka J, Lindfors T, McCarrick M, Ivaska A, Lewenstam A (1995) Anal Chem 67:3819-3823

27. Bobacka J, Ivaska A, Lewenstam A (1999) Anal Chim Acta 385:195-202

28. Song F, Ha J, Park B, Kwak TH, Kim IT, Nam H, Cha GS (2002) Talanta 57:263-270 
29. Sjöberg-Eerola P, Bobacka J, Sokalski T, Mieczkowiski MJ, Ivaska A, Lewenstam A (2004) Electroanalysis 16:379-385

30. Bobacka J (1999) Anal Chem 71:4932-4937

31. Vázquez M, Bobacka J, Ivaska A, Lewenstam A (2002) Sens. Actuators B 82:7-13

32. Michalska A, Dumanska J, Maksymiuk K (2003) Anal Chem 75:4964-4974

33. Michalska A, Appaih-Kusi C, Heng LY, Walkiewicz S, Hall EAH (2004) Anal Chem 76:2031-2039

34. Michalska A, Maksymiuk K (2004) Talanta 65:109-117

35. Morf WE, Badertscher M, Zwickl T, de Rooij NF, Pretsch E (2002) J Electroanal Chem 526:19-28

36. Dumanska J, Maksymiuk K (2001) Electroanalysis 13:567-573

37. Fibbioli M, Morf WE, Badertscher M, de Rooij NF, Pretsch E (2000) Electroanalysis 12:1286-1292
38. Sutter J, Radu A, Peper S, Bakker E, Pretsch E (2004) Anal Chim Acta (in press)

39. Gyurcsányi RE, Rangisetty N, Clifton S, Pendley BD, Lindner E (2004) Talanta 63:89-99

40. Ceresa A, Bakker E, Günther D, Hattendorf B, Pretsch E (2001) Anal Chem 73:343-351

41. Bakker E (1997) Anal Chem 69:1061-1069

42. Bakker E, Pretsch E, Bühlmann P (2000) Anal Chem 72:11271133

43. Heng LY, Tóth K, Hall EAH (2004) Talanta 63:73-87

44. Ceresa A, Radu A, Peper S, Bakker E, Pretsch E (2002) Anal Chem 74:4027-4036

45. Bühlmann $\mathrm{P}$, Yajima $\mathrm{S}$, Tohda $\mathrm{K}$, Umezawa $\mathrm{K}$, Nishizawa $\mathrm{S}$, Umezawa Y (1995) Electroanalysis 7:811-816 